\title{
Mutational escape of CD8+ $T$ cell epitopes: implications for prevention and therapy of persistent hepatitis virus infections
}

\author{
Joerg Timm $\cdot$ Christopher M. Walker
}

Received: 11 March 2014 / Accepted: 1 September 2014 / Published online: 24 December 2014

(C) The Author(s) 2014. This article is published with open access at Springerlink.com

\begin{abstract}
Over the past two decades, much has been learned about how human viruses evade $\mathrm{T}$ cell immunity to establish persistent infection. The lessons are particularly relevant to two hepatotropic viruses, $\mathrm{HBV}$ and $\mathrm{HCV}$, that are very significant global public health problems. Although HCV and HBV are very different, the natural history of persistent infections with these viruses in humans shares some common features including failure of $\mathrm{T}$ cell immunity. During recent years, large sequence studies of $\mathrm{HCV}$ have characterized intra-host evolution as well as sequence diversity between hosts in great detail. Combined with studies of CD8+ $\mathrm{T}$ cell phenotype and function, it is now apparent that the $\mathrm{T}$ cell response shapes viral evolution. In turn, HCV sequence diversity influences the quality of the CD8+ $\mathrm{T}$ cell response and thus infection outcome. Here, we review published studies of CD8 $+\mathrm{T}$ cell selection pressure and mutational escape of the virus. Potential consequences for therapeutic strategies to restore $\mathrm{T}$ cell immunity against persistent human viruses, most notably $\mathrm{HBV}$, are discussed.
\end{abstract}

This article is part of the special issue "Therapeutic vaccination in chronic hepatitis B-approaches, problems, and new perspectives".

J. Timm $(\bowtie)$

Institute of Virology, University Hospital Düsseldorf, Heinrich-

Heine-University, Universitätsstrasse 1, 40225 Düsseldorf,

Germany

e-mail: joerg.timm@med.uni-duesseldorf.de

C. M. Walker

Department of Pediatrics, The Ohio State University School of Medicine, Columbus, OH, USA

e-mail: christopher.walker@nationwidechildrens.org
Keywords Hepatitis C virus · Hepatitis B virus · Immunotherapy $\cdot$ Exhaustion $\cdot$ PD-1

\section{Introduction}

Although the natural history of persistent HCV and HBV infections in humans is different, failure of $\mathrm{T}$ cell immunity is a common feature. Many of the same defects in $\mathrm{T}$ cell immunity have been described in both infections. For instance, an absence of sustained virus-specific CD4+ helper $\mathrm{T}$ cell immunity is central to development of chronic $\mathrm{HBV}$ and HCV infection. Cytotoxic CD8+ T cells persist in the liver after chronic infections are established, but lack key effector functions, a state defined as exhaustion. Whether exhaustion can be reversed by vaccination and/or interference with inhibitory signaling pathways that are active in exhausted CD8+ T cells is of current interest, especially for HBV where treatment options for long-term control of infection are limited. Some CD8 $+\mathrm{T}$ cell populations appear to be more exhausted than others during persistent virus infections, depending on whether viral class I epitopes have acquired mutations and evade recognition by $\mathrm{CD} 8+\mathrm{T}$ cells. Substantial evidence supporting this concept has come from studies of HCV, a virus that is classified into seven different genotypes and multiple subtypes that differ up to $20 \%$ at the amino acid level. During recent years, comparison of large number of $\mathrm{HCV}$ sequences has provided detailed insight into intra-host evolution as well as sequence diversity between hosts. Combined with studies of CD8+ T cell phenotype and function, it is now apparent that the response shapes viral evolution. In turn, HCV sequence diversity influences the quality of the $\mathrm{CD} 8+\mathrm{T}$ cell response and thus infection outcome. Here, we review published studies of 
$\mathrm{CD} 8+\mathrm{T}$ cell selection pressure and mutational escape of the virus.

\section{Evidence for $\mathrm{CD8}+\mathrm{T}$ cell selection pressure and $\mathrm{HCV}$ evolution}

HCV particles harbor a positive-strand RNA genome that is directly translated in the cytosol of infected cells into a polyprotein approximately 3,000 amino acids in length. The polyprotein is cleaved by cellular and viral proteases into functional units. The virus encodes an RNA-dependent RNA polymerase ( $\mathrm{RdRp}$ ) located at the C-terminal end of the polyprotein (NS5B) that is needed for RNAreplication. Due to the lack of a proofreading function by the RdRp, viral replication is error prone and results in a swarm of multiple closely related but distinct viral variants termed as quasispecies. In response to selection pressure, viral variants that are best adapted for survival emerge from the quasispecies. It is now well established that $\mathrm{CD} 8+\mathrm{T}$ cells are a significant source of selection pressure against $\mathrm{HCV}$, most notably during the acute phase of infection. The $\mathrm{CD} 8+\mathrm{T}$ cell response is highly individualized because multiple distinct allotypes with different epitope binding properties exist for HLA class I A, B and C genes. Transmission of the virus to a new host can therefore cause a dramatic shift in the epitope repertoire recognized by $\mathrm{CD} 8+\mathrm{T}$ cells.

Evidence that $\mathrm{HCV}$ adapts to $\mathrm{CD} 8+\mathrm{T}$ cell immune pressure by selection of substitutions in targeted epitopes was first obtained in the chimpanzee model $[1,2]$, which was well suited for these studies because viruses with a defined genome sequence could be used to initiate infection. Similar studies were subsequently carried out in infected humans under circumstances where the genomic sequences of donor and recipient viruses were available for comparison [3, 4]. Analysis of virus evolution in the chimpanzees and humans revealed a much higher rate of non-synonymous mutation in class I epitopes when compared with other regions of the HCV genome not under selection pressure by $\mathrm{CD} 8+\mathrm{T}$ cells. The most comprehensive human study was performed in a cohort of eight people who inject drugs (PWID) with acute HCV genotype 1a infection [5]. Approximately $50 \%$ of the class I epitopes acquired non-synonymous substitutions that facilitated escape from CD8+ $\mathrm{T}$ cell recognition. In turn, about $50 \%$ of the substitutions in the non-structural proteins were associated with a detectable $\mathrm{CD} 8+\mathrm{T}$ cell response. Other studies of human subjects are consistent with these findings [6-9]. The impact of CD8+ T cells on virus evolution has also been examined by aligning HCV amino acid polymorphisms and patterns of HLA class I allele expression in large populations of $\mathrm{HCV}$-infected patients. These analyses provided additional evidence, even in the absence of donor virus genome sequences, that escape mutation is a very common and partially predictable feature of $\mathrm{HCV}$ infections that persist [10-13].

An increased rate of non-synonymous mutation in class I epitopes versus flanking regions was predominantly observed during the acute phase in human [6] and chimpanzee $[14,15]$ infections that ultimately persisted. As an example, in chimpanzees infected with clonal HCV genomes, non-synonymous mutation in class I epitopes was highest during the first 8-12 months of infection [14], just before CD8+ $\mathrm{T}$ cell selection pressure is thought to gradually fail. Once chronic infection was established, the rate of non-synonymous mutation is not substantially different between class I epitopes and flanking regions of the HCV genome. This suggests that the capacity of CD8 $+\mathrm{T}$ cells to recognize escape variants within epitopes, or to broaden to new epitopes, is limited during the chronic phase of infection. Consistent with these observations, escape mutations in $\mathrm{HCV}$ epitopes that arise during the acute phase are usually stable through decades of chronic infection [9, 16, 17] and de novo responses against new epitopes are equally rare [18]. This is quite different from the situation in persistent HIV infection where expansion of "escape-specific" CD8 T cells after selection of substitutions inside epitopes has been described $[19,20]$, most commonly for class I alleles such as HLA-B*27 and HLA-B*57 associated with protection from disease progression [21-24]. The HIV-specific CD8+ T cell response can also further broaden over the course of infection [25, 26]. Why the $\mathrm{HCV}$-specific CD8+ T cell response fails to keep pace with virus evolution or broaden to new epitopes is not known. It might be explained by the concept of original antigenic sin, defined as impairment of a secondary immune response against a distinct but closely related antigen. This concept was described for CD8 $+\mathrm{T}$ cells in some murine models of virus infection [27], although it appears not to be universally operational in all settings [28]. Failure of CD8 $+\mathrm{T}$ cells to recognize new or escaped HCV epitopes may coincide with the profound, but as yet unexplained absence of HCV-specific CD4+ T cells during chronic infection [29]. Loss of CD4+ T cell help during the acute phase of infection might facilitate the initial emergence of escape variants. In support of this concept, one study in chimpanzees documented that antibody-mediated depletion of CD4 $+\mathrm{T}$ cells facilitated epitope escape from CD8+ T cells [30]. Further research is needed, however, to determine how an absence of helper activity during the acute and chronic phases of infection contributes to virus evolution and the capacity of $\mathrm{CD} 8+\mathrm{T}$ cells to exert selection pressure. 


\section{Functional mechanisms underpinning escape of class I epitopes}

Mutation of even a single amino acid within an HCV epitope can defeat CD8 $+\mathrm{T}$ cell recognition through multiple mechanisms. One dominant mechanism involves mutation of an epitope anchor residue required for binding to the MHC class I molecule. Suboptimal binding leads to an unstable MHC class I/peptide complex and loss of the epitope. This appears to be the most frequent mechanism of immune escape for HIV because the majority of selected substitutions are located at these important anchor residues [31, 32]. Whether anchor residue substitutions are also the most common mechanism for mutational escape of HCV has not yet been determined. Amino acid substitutions at non-anchor residues can also impair CD8+ T cell recognition if they are located at the interface of the $\mathrm{T}$ cell receptor (TcR) and MHC class I/peptide complex. In this case, the variant epitope is still presented by the MHC class I molecule, but TcR binding is impaired. In the chimpanzee model, there is evidence that this mechanism of mutational immune escape is associated with a narrow TcR repertoire, whereas a broader repertoire may prevent viral escape, possibly due to enhanced cross-reactivity with more sequence variants of the epitope [33]. This observation suggests that $\mathrm{CD} 8+\mathrm{T}$ cell populations may be qualitatively different in their capacity of immune selection. The ability to recognize multiple variants of a class I epitope may be the most important during the acute phase of infection before effective CD4+ and CD8+ T cell immunity is lost.

Finally, selected amino acid substitutions may alter processing of $\mathrm{CD} 8+\mathrm{T}$ cell epitopes. Antigen presentation is a multi-step process that requires proteasomal degradation of viral proteins, transport to the endoplasmic reticulum, N-terminal trimming by amino peptidases and transport of the stabilized MHC class I/peptide complex to the cell surface. Many of these steps are sequence dependent and variation inside or near the epitope could alter this process. For example, it has been shown that substitutions inside the epitope can disrupt the endogenously processed epitope by preferential cleavage inside the epitope by the proteasome [34]. Altered epitope processing was also associated with substitutions in the C-terminal flanking region of an HLA-A*02-restricted epitope [35]. Whether such substitutions in the epitope flanking region are indeed selected by $\mathrm{CD} 8+\mathrm{T}$ cell immune pressure is less clear. We recently identified a substitution five amino acids upstream of an HLA-B*51-restricted epitope in NS3 that is significantly more frequent in HLA-B*51positive patients infected with $\mathrm{HCV}$ genotype 1a (unpublished). Functional analysis revealed that this substitution impaired antigen processing supporting that selection of altered epitope processing contributes to $\mathrm{CD} 8+\mathrm{T}$ cell immune escape, although the overall extent of this viral escape pathway is unclear in hepatitis $\mathrm{C}$.

\section{Relevance of CD8+ $\mathrm{T}$ cell escape mutations to infection outcome}

Mutational escape of HIV from dominant CD8+ T cell responses is associated with increased replication of the persistent virus and progression to AIDS [36-38]. Whether escape mutations in class I epitopes determine whether acute $\mathrm{HCV}$ infection will ultimately resolve or persist is less clear. Viral mutational escape may simply be a consequence of continuous viral replication in the presence of selection pressure and not causal for viral persistence. Studies in chimpanzees experimentally infected with welldefined strains of the HCV revealed that class I escape mutations are much less common in infections that resolve spontaneously when compared with those that persist [2]. These studies are much more difficult to perform in humans because the acute phase of infection is often unrecognized due to mild or inapparent symptoms and the sequence of the donor virus is often not known. One study has nonetheless documented that escape mutations are also less frequent in acute resolving versus persistent $\mathrm{HCV}$ infections in humans [5]. Despite these associations, a convincing causal relationship between class I epitope escape and infection outcome has not been established. Such an analysis is likely to be complicated by multiple factors including the breadth of the CD8+ T cell response, whether viral fitness for replication is impaired by mutation of dominant epitopes, and the timing of CD4+ $\mathrm{T}$ cell loss and CD8+ T cell exhaustion during acute hepatitis $\mathrm{C}$.

The impact of escape mutations and infection outcome is also likely to be influenced by HLA haplotype. Protective HLA class I alleles that correlate with better infection outcome have been identified for HIV [39] and HCV [40-42]. In HIV, there is evidence that immune control can be maintained despite selection of escape mutations in key epitopes presented by protective class I alleles like HLA$\mathrm{B} * 27$ and HLA-B*57 [23, 43-45]. These key epitopes are constrained from mutation because of excessive fitness costs and selection of unfit viral variants may even be causal for viral containment [31, 46-48]. This would suggest that viral constraints determine the protective effect of particular HLA class I alleles. On the other hand, it has been argued that the epitopes presented by protective HLA class I alleles are targeted by T cells with stronger or more sustained antiviral activity [49]. There are strong arguments for both concepts, and successful control of infection might require a combination of both the "right" $\mathrm{T}$ cells against the "right" epitopes. It is notable that HLA-B*27 
and HLA-B $* 57$ are also associated with protection against HCV persistence. These two alleles, along with the protective allele HLA-A*03, present HCV epitopes that are nonetheless prone to mutational escape [50-52]. An important difference between these "protective" epitopes and "conventional" epitopes presented by other alleles may again be the genetic barrier to resistance. Mutational escape of HCV is also associated with varying degrees of fitness cost [13, 16, 17, 53]. Consequently, many escape mutations revert back to the prototype sequence in the absence of immune pressure $[3,54]$. This has most recently been described in chronically infected pregnant women, where selection pressure is thought to be attenuated because of changes in maternal immunity to protect the fetus [55]. The genetic barrier to viral escape may be particularly high when the impact of mutation on virus replication is severe and/ or a complex pattern of multiple substitutions is required to achieve full immune escape, as shown for dominant HCV epitopes presented by protective alleles [51, 56-58]. For immune escape from the dominant HLA-A*03- and HLA-B*57-restricted CD8 $+\mathrm{T}$ cell epitopes, secondary mutations were required to compensate for fitness costs associated with the primary escape mutation [51, 56, 58]. Interestingly, the dominant HLA-B*27 epitope was unique in that fitness was not impaired by mutational escape; here, cross-reactivity of epitope-specific CD8 T cells with different variants required multiple substitutions to achieve full escape [57].

Collectively, these data suggest that important qualitative differences exist between $\mathrm{CD} 8+\mathrm{T}$ cell responses. For successful immune control and containment of HCV replication, a strong and ideally broadly cross-reactive CD8+ $\mathrm{T}$ cell response associated with a high genetic barrier to mutational immune escape is needed. Identification of these epitopes requires a combined analysis of the CD8+ T cell immune response in concert with viral sequences.

\section{Immunogenicity of CD8+ T cell escape variants}

The clinical consequences of transmission of escape mutations are largely unclear for HCV. There are studies suggesting that the beneficial effect of particular HLA class I alleles is specific to individual HCV genotypes or even subtypes $[52,59]$. This may be attributable to sequence differences in immunodominant CD8 $+\mathrm{T}$ cell epitopes restricted by these "protective" HLA alleles. For example, the advantageous effect of HLA-B*27 was so far only reported in HCV genotype 1 cohorts and was linked to a single epitope located in NS5B. Of note, the typically selected escape variant in genotype 1 resembles the prototype sequence in genotype 3. Interestingly, there is evidence that HLA-B*27 is not protective against $\mathrm{HCV}$ genotype $3 \mathrm{a}$, suggesting that preexisting substitutions in the prototype HLA-B*27restricted epitope precluded a dominant immune response [50]. Similarly, HLA-B $* 57$ was reported to be associated with beneficial outcome only in cohorts infected predominantly with HCV genotype 1a [41, 52], whereas HLA$B * 57$ was not protective in cohorts infected with genotype $1 \mathrm{~b}$ [40]. Again, it has been highlighted that genotype $1 \mathrm{~b}$ typically harbors a variant of the dominant prototype epitope sequence in $\mathrm{HCV}$ genotype 1a that is associated with lack of the immune response [52]. Although these studies describe the impact of genotype or subtype-specific sequence differences on the outcome of infection, similar effects seem possible when it comes to transmission of escape mutations. Studies that directly address this are difficult to perform, because the exact viral sequence at the time of transmission is usually unknown. However, there are two large single-source outbreaks of hepatitis $\mathrm{C}$ for which the viral sequence of the inoculum is known and thus allow conclusions on the relevance of transmitted sequence variants in important CD8 $\mathrm{T}$ cell epitopes $[9,54]$. In a large outbreak of HCV genotype $1 b$ in Ireland, HLA$A * 03$ and HLA-B*27 were associated with spontaneous immune control, whereas HLA-B*08 was associated with viral persistence [40]. Interestingly, in a second very similar HCV genotype 1b outbreak in East Germany via the same transmission route, all three HLA alleles were neutral for the infection outcome [60]. This correlated with preexisting substitutions in the dominant epitopes presented by HLA-A*03 and HLA-B*27 in the source of the East-German outbreak, whereas the dominant epitope presented by HLA-B*08 was prototype. Notably, the same HLA-B*08 epitope carried substitutions in the source of the Irish outbreak possibly explaining the disadvantageous effect of HLA-B*08 specific for this cohort [54]. Although not conclusive, this strongly suggests that transmission of CD8 $\mathrm{T}$ cell escape variants is disadvantageous for the clinical outcome of a recipient who carries the same HLA alleles. Mutational escape of class I epitopes may also be an issue in the unique setting of pregnancy, where as noted above, some escape mutations can revert to wild-type sequence and cause an increase in viral fitness for replication [55]. It appears that the more fit viruses are transmitted vertically to infants, but more study is required to define the influence of maternal and paternal HLA haplotype on virus evolution and replication in this special population.

CD8 $\mathrm{T}$ cell responses against variant epitopes after mutational escape have only been reported in individual cases $[16,17]$. It is unclear whether $\mathrm{T}$ cells with the relevant TCR are missing, whether they are anergic once chronic infection was established in the liver, or whether they are activated, but below the detection limit in the peripheral blood. Lack of $\mathrm{T}$ cells reactive with an escape variant of an HLA-A*02-restricted CD8 T cell epitope in 
Fig. 1 Impact of mutational antigen escape on the phenotype of specific CD8+ T cells during chronic HCV infection. Continuous antigen stimulation of $\mathrm{CD} 8+\mathrm{T}$ cells results in $\mathrm{T}$ cell exhaustion associated with poor antiviral function. In contrast, after mutational escape CD8+ T cells develop a "memory" phenotype (CD127 high) with high proliferative potential upon stimulation with the cognate antigen and better antiviral efficacy
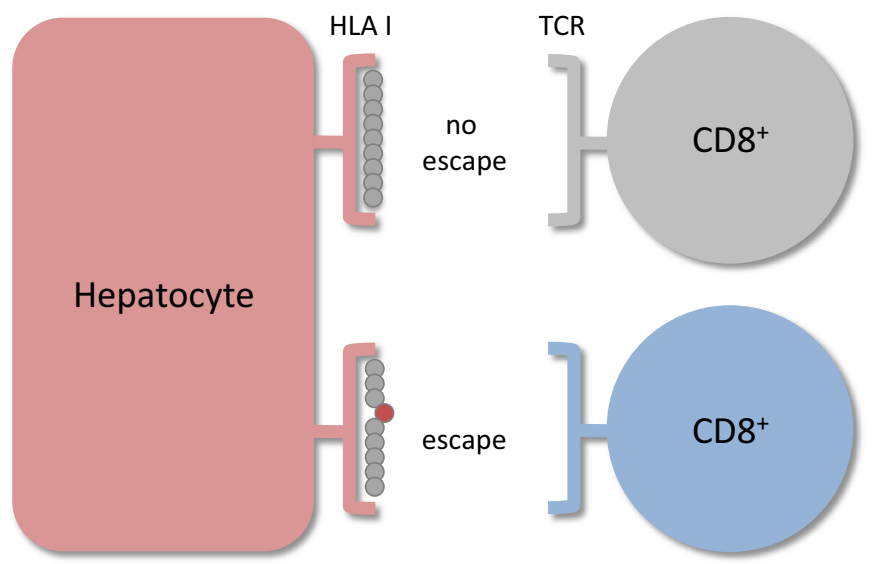

- CD127 - low

- PD-1 - high

- KLRG1 - high

- proliferative potential - low

- antiviral efficacy - low



- CD127 - high

- PD-1 - low

- KLRG1 - low

- proliferative potential - high

- antiviral efficacy - medium
NS3 was demonstrated [61]. In a study that analyzed CD8 $\mathrm{T}$ cell cross-reactivity between HCV genotype 1 and 3, an HLA-B*13-restricted epitope was identified that differed in one amino acid position [62]. Interestingly, in a cohort of people who inject drugs frequently exposed to genotype 1 and 3, co-existence of two distinct CD8 T cell populations against both genotypes, each without cross-reactivity, was reproducibly observed [62]. Although here the sequence differences were not the consequence of mutational escape, this suggests that a second CD8 $\mathrm{T}$ cell response against a closely related sequence variant can be activated also in HCV. Further studies are needed to address, whether and to what extent priming and activation of CD8 T cells directed against escape variants of $\mathrm{HCV}$ epitopes is possible during chronic infection.

\section{Impact of mutational escape on $\mathrm{CD8}+\mathrm{T}$ cell function and capacity for immune restoration}

The number of epitopes that acquire escape mutations is variable, but $50 \%$ or more do remain intact through the chronic phase of infection even though cognate CD8+ T cells survive in the liver. Exhaustion, characterized by a progressive loss of effector functions when continuously stimulated with antigen, almost certainly accounts for failure of these CD8+ T cells to control HCV replication [63]. Exhaustion is associated with increased expression of multiple inhibitory receptors such as PD-1, Tim-3, CTLA-4, 2B4 and LAG-3 and reduced expression of CD127 and the IL7 receptor-alpha chain that is required for self-renewal of memory populations [64-70]. Interestingly, this exhausted phenotype changes when escape mutations are introduced into class I-restricted epitopes (Fig. 1). HCV-specific $\mathrm{CD} 8+\mathrm{T}$ cells targeting escaped epitopes display less PD-1 and more CD127 [64, 71, 72]. Moreover, proliferation is more robust upon antigen stimulation and they appear to retain or regain effector functions [64] when compared with CD8+ T cells with an exhausted phenotype that target intact epitopes. CD8 $+\mathrm{T}$ cells with a less exhausted phenotype also have an enhanced capacity to suppress HCV replication in a cell co-culture model after stimulation with a variety of cytokines or blockade of the PD-1 signaling pathway [73].

These observations suggest that immunotherapeutic vaccination or blockade of co-inhibitory signaling pathways may be more likely to reverse exhaustion of CD8+ T cells that target escaped versus intact class I epitopes. Studies in humans and chimpanzees suggest that both approaches can mobilize HCV-specific T cells and reduce virus load in a subset of chronically infected patients. For instance, reduction of virus load in a subset of patients after vaccination with a poxvirus vaccine that expressed non-structural HCV proteins has been reported [74]. Antibody-mediated blockade of the PD-1 co-inhibitory signaling pathway was also undertaken in humans [75] and chimpanzees [76], but again reduction of virus load was achieved only in a small subset of those who were treated. Of ten humans treated with a single high dose of anti-PD-1 antibodies $(10 \mathrm{mg} /$ $\mathrm{kg} \mathrm{BW}$ ), three had a remarkable reduction in HCV RNA in plasma of at least 10,000-fold which remained persistently undetectable in one of them after treatment. Of note, one patient with grade 4 ALT elevation ( $>10 \times$ upper limit of normal range) also had a significant decline in viral load. One chimpanzee of three treated with 5 weekly doses of anti-PD-1 antibodies ( $3 \mathrm{mg} / \mathrm{kg} \mathrm{BW}$ ) showed a substantial reduction in viremia that reverted to baseline levels with discontinuation of therapy [76]. The responder showed robust post-treatment expansion of intrahepatic HCVspecific CD4+ and CD8+ T cells when compared with the two non-responder animals [76]. Better characterization of the $\mathrm{T}$ cell response and viral sequences from the treated patients will be required to determine why many of those treated with the therapeutic poxvirus vaccine or anti-PD-1 antibodies failed to respond. Whether they had a more exhausted phenotype or primarily targeted 
epitopes that had acquired escape mutations remains to be determined. Although even after mutational escape of the epitope CD8 T cells may partially contribute to viral containment [55], it seems unlikely that activation and expansion of these CD8+ T cells is sufficient for viral eradication when the targeted antigen is not intact.

\section{Do escape mutations matter for prevention or treatment of chronic infection?}

With the rapid development of type I interferon-free directacting antiviral agents against $\mathrm{HCV}$, immunotherapeutic vaccination and/or blockade of co-inhibitory signaling pathways are unlikely to be considered for treatment of chronic hepatitis C. However, there is consensus that a prophylactic vaccine will be needed to prevent $\mathrm{HCV}$ infection in groups at high risk of infection [77, 78], and perhaps as importantly to prevent reinfection after expensive DAAmediated cure of chronic hepatitis C [79]. One study in a chimpanzee cured of chronic infection with DAA revealed a substantial difference in responsiveness of $\mathrm{T}$ cells to escaped and intact epitopes upon reinfection with $\mathrm{HCV}$ 2 years later [80]. Only CD8+ T cells targeting epitopes that had escaped during the first infection expanded in liver upon reinfection. They provided transient control of virus replication that ultimately failed as viruses with new escape mutations in the dominant epitopes rapidly emerged. These observations, although very preliminary and restricted to a single treated individual, suggest that escape mutations can skew T cell responsiveness long after cure of infection. Vaccination after cure may be required to either restore $\mathrm{CD} 8+\mathrm{T}$ cell responses to epitopes that were intact or to broaden the repertoire to new epitopes.

For HBV, direct-acting antivirals only suppress replication of the viral genome, usually without a significant impact on production of viral proteins thought to be responsible for $\mathrm{T}$ cell exhaustion. There is renewed interest in immunotherapy to reverse the immune tolerant state and reduce the risk of serious long-term liver diseases. Combination therapies to reduce production of viral antigens that exhaust $\mathrm{T}$ cells, and at the same time restore their function by vaccination or blockade of co-inhibitory signaling, are receiving attention. The promise of combination therapy using these approaches was elegantly demonstrated by Roggendorf and colleagues in the woodchuck model of persistent HBV infection [81, 82]. These findings almost certainly herald the start of a new era of therapy for chronic hepatitis B, a disease that affects more than 240 million people globally. Importantly, escape mutations in class I epitopes have been described in patients with chronic hepatitis B [83], but whether they are important for CD8+ T cell evasion or alter the course of infection is very poorly understood when compared with HIV and HCV infection. Translation of very promising new therapies from animals to humans would likely benefit from a more detailed understanding of how escape mutations influence the repertoire, phenotype and function of CD8+ T cells in humans persistently infected with HBV.

Conflict of interest The authors declare that they have no conflicts of interest.

Open Access This article is distributed under the terms of the Creative Commons Attribution License which permits any use, distribution, and reproduction in any medium, provided the original author(s) and the source are credited.

\section{References}

1. Cooper S, Erickson AL, Adams EJ, Kansopon J, Weiner AJ, Chien DY, Houghton M, Parham P, Walker CM (1999) Analysis of a successful immune response against hepatitis $\mathrm{C}$ virus. Immunity 10(4):439-449

2. Erickson AL, Kimura Y, Igarashi S, Eichelberger J, Houghton M, Sidney J, McKinney D, Sette A, Hughes AL, Walker CM (2001) The outcome of hepatitis $C$ virus infection is predicted by escape mutations in epitopes targeted by cytotoxic $\mathrm{T}$ lymphocytes. Immunity 15(6):883-895

3. Timm J, Lauer GM, Kavanagh DG, Sheridan I, Kim AY, Lucas M, Pillay T, Ouchi K, Reyor LL, Schulze zur Wiesch J, Gandhi RT, Chung RT, Bhardwaj N, Klenerman P, Walker BD, Allen TM (2004) CD8 epitope escape and reversion in acute HCV infection. J Exp Med 200(12):1593-1604

4. Tester I, Smyk-Pearson S, Wang P, Wertheimer A, Yao E, Lewinsohn DM, Tavis JE, Rosen HR (2005) Immune evasion versus recovery after acute hepatitis $\mathrm{C}$ virus infection from a shared source. J Exp Med 201(11):1725-1731

5. Cox AL, Mosbruger T, Mao Q, Liu Z, Wang XH, Yang HC, Sidney J, Sette A, Pardoll D, Thomas DL, Ray SC (2005) Cellular immune selection with hepatitis $\mathrm{C}$ virus persistence in humans. $\mathrm{J}$ Exp Med 201(11):1741-1752

6. Kuntzen T, Timm J, Berical A, Lewis-Ximenez LL, Jones A, Nolan B, Schulze zur Wiesch J, Li B, Schneidewind A, Kim AY, Chung RT, Lauer GM, Allen TM (2007) Viral sequence evolution in acute hepatitis C virus infection. J Virol 81(21):11658-11668

7. Pfafferott K, Gaudieri S, Ulsenheimer A, James I, Heeg M, Nolan D, John M, Rauch A, Mallal S, Lucas A, Klenerman P, Diepolder HM, Lucas M (2011) Constrained pattern of viral evolution in acute and early $\mathrm{HCV}$ infection limits viral plasticity. PLoS One 6(2):e16797

8. Merani S, Petrovic D, James I, Chopra A, Cooper D, Freitas E, Rauch A, di Iulio J, John M, Lucas M, Fitzmaurice K, McKiernan S, Norris S, Kelleher D, Klenerman P, Gaudieri S (2011) Effect of immune pressure on hepatitis $\mathrm{C}$ virus evolution: insights from a single-source outbreak. Hepatology 53(2):396-405

9. Ruhl M, Knuschke T, Schewior K, Glavinic L, Neumann-Haefelin C, Chang DI, Klein M, Heinemann FM, Tenckhoff H, Wiese M, Horn PA, Viazov S, Spengler U, Roggendorf M, Scherbaum N, Nattermann J, Hoffmann D, Timm J, East German HCVSG (2011) CD8+ T-cell response promotes evolution of hepatitis C virus nonstructural proteins. Gastroenterology 140(7):2064-2073

10. Timm J, Li B, Daniels MG, Bhattacharya T, Reyor LL, Allgaier R, Kuntzen T, Fischer W, Nolan BE, Duncan J, Schulze zur Wiesch J, Kim AY, Frahm N, Brander C, Chung RT, Lauer GM, 
Korber BT, Allen TM (2007) Human leukocyte antigen-associated sequence polymorphisms in hepatitis $\mathrm{C}$ virus reveal reproducible immune responses and constraints on viral evolution. Hepatology 46(2):339-349

11. Gaudieri S, Rauch A, Park LP, Freitas E, Herrmann S, Jeffrey G, Cheng W, Pfafferott K, Naidoo K, Chapman R, Battegay M, Weber R, Telenti A, Furrer H, James I, Lucas M, Mallal SA (2006) Evidence of viral adaptation to HLA class I-restricted immune pressure in chronic hepatitis $\mathrm{C}$ virus infection. J Virol 80(22):11094-11104

12. Rauch A, James I, Pfafferott K, Nolan D, Klenerman P, Cheng W, Mollison L, McCaughan G, Shackel N, Jeffrey GP, Baker R, Freitas E, Humphreys I, Furrer H, Gunthard HF, Hirschel B, Mallal S, John M, Lucas M, Barnes E, Gaudieri S (2009) Divergent adaptation of hepatitis $C$ virus genotypes 1 and 3 to human leukocyte antigen-restricted immune pressure. Hepatology 50(4):1017-1029

13. Neumann-Haefelin C, Frick DN, Wang JJ, Pybus OG, Salloum S, Narula GS, Eckart A, Biezynski A, Eiermann T, Klenerman P, Viazov S, Roggendorf M, Thimme R, Reiser M, Timm J (2008) Analysis of the evolutionary forces in an immunodominant CD8 epitope in hepatitis $\mathrm{C}$ virus at a population level. J Virol 82(7):3438-3451

14. Callendret B, Bukh J, Eccleston HB, Heksch R, Hasselschwert DL, Purcell RH, Hughes AL, Walker CM (2011) Transmission of clonal hepatitis $\mathrm{C}$ virus genomes reveals the dominant but transitory role of CD8 $+\mathrm{T}$ cells in early viral evolution. J Virol 85(22):11833-11845

15. Fernandez J, Taylor D, Morhardt DR, Mihalik K, Puig M, Rice CM, Feinstone SM, Major ME (2004) Long-term persistence of infection in chimpanzees inoculated with an infectious hepatitis $\mathrm{C}$ virus clone is associated with a decrease in the viral amino acid substitution rate and low levels of heterogeneity. J Virol 78(18):9782-9789

16. Uebelhoer L, Han JH, Callendret B, Mateu G, Shoukry NH, Hanson HL, Rice CM, Walker CM, Grakoui A (2008) Stable cytotoxic $\mathrm{T}$ cell escape mutation in hepatitis $\mathrm{C}$ virus is linked to maintenance of viral fitness. PLoS Pathog 4(9):e1000143

17. Salloum S, Oniangue-Ndza C, Neumann-Haefelin C, Hudson L, Giugliano S, aus dem Siepen M, Nattermann J, Spengler U, Lauer GM, Wiese M, Klenerman P, Bright H, Scherbaum N, Thimme R, Roggendorf M, Viazov S, Timm J (2008) Escape from HLA-B*08-restricted CD8 $\mathrm{T}$ cells by hepatitis $\mathrm{C}$ virus is associated with fitness costs. J Virol 82(23):11803-11812

18. Cox AL, Mosbruger T, Lauer GM, Pardoll D, Thomas DL, Ray SC (2005) Comprehensive analyses of CD8+ T cell responses during longitudinal study of acute human hepatitis C. Hepatology 42(1):104-112

19. Allen TM, Yu XG, Kalife ET, Reyor LL, Lichterfeld M, John M, Cheng M, Allgaier RL, Mui S, Frahm N, Alter G, Brown NV, Johnston MN, Rosenberg ES, Mallal SA, Brander C, Walker BD, Altfeld M (2005) De novo generation of escape variant-specific CD8+ T-cell responses following cytotoxic T-lymphocyte escape in chronic human immunodeficiency virus type 1 infection. J Virol 79(20):12952-12960

20. Roider J, Kalteis AL, Vollbrecht T, Gloning L, Stirner R, Henrich N, Bogner JR, Draenert R (2013) Adaptation of CD8 T cell responses to changing HIV-1 sequences in a cohort of HIV-1 infected individuals not selected for a certain HLA allele. PLoS One 8(12):e80045

21. Feeney ME, Tang Y, Pfafferott K, Roosevelt KA, Draenert R, Trocha A, Yu XG, Verrill C, Allen T, Moore C, Mallal S, Burchett S, McIntosh K, Pelton SI, St John MA, Hazra R, Klenerman P, Altfeld M, Walker BD, Goulder PJ (2005) HIV-1 viral escape in infancy followed by emergence of a variant-specific CTL response. J Immunol 174(12):7524-7530
22. O'Connell KA, Hegarty RW, Siliciano RF, Blankson JN (2011) Viral suppression of multiple escape mutants by de novo CD8(+) $\mathrm{T}$ cell responses in a human immunodeficiency virus- 1 infected elite suppressor. Retrovirology 8:63

23. Bailey JR, Williams TM, Siliciano RF, Blankson JN (2006) Maintenance of viral suppression in HIV-1-infected HLAB*57 + elite suppressors despite CTL escape mutations. J Exp Med 203(5):1357-1369

24. Ladell K, Hashimoto M, Iglesias MC, Wilmann PG, McLaren JE, Gras S, Chikata T, Kuse N, Fastenackels S, Gostick E, Bridgeman JS, Venturi V, Arkoub ZA, Agut H, van Bockel DJ, Almeida JR, Douek DC, Meyer L, Venet A, Takiguchi M, Rossjohn J, Price DA, Appay V (2013) A molecular basis for the control of preimmune escape variants by HIV-specific CD $8+\mathrm{T}$ cells. Immunity 38(3):425-436

25. Altfeld M, Kalife ET, Qi Y, Streeck H, Lichterfeld M, Johnston MN, Burgett N, Swartz ME, Yang A, Alter G, Yu XG, Meier A, Rockstroh JK, Allen TM, Jessen H, Rosenberg ES, Carrington M, Walker BD (2006) HLA alleles associated with delayed progression to AIDS contribute strongly to the initial CD8+ T cell response against HIV-1. PLoS Med 3(10):e403

26. Altfeld M, Rosenberg ES, Shankarappa R, Mukherjee JS, Hecht FM, Eldridge RL, Addo MM, Poon SH, Phillips MN, Robbins GK, Sax PE, Boswell S, Kahn JO, Brander C, Goulder PJ, Levy JA, Mullins JI, Walker BD (2001) Cellular immune responses and viral diversity in individuals treated during acute and early HIV-1 infection. J Exp Med 193(2):169-180

27. Klenerman P, Zinkernagel RM (1998) Original antigenic sin impairs cytotoxic $\mathrm{T}$ lymphocyte responses to viruses bearing variant epitopes. Nature 394(6692):482-485

28. Zehn D, Turner MJ, Lefrancois L, Bevan MJ (2010) Lack of original antigenic $\sin$ in recall $\mathrm{CD} 8+\mathrm{T}$ cell responses. J Immunol 184(11):6320-6326

29. Schulze Zur Wiesch J, Ciuffreda D, Lewis-Ximenez L, Kasprowicz V, Nolan BE, Streeck H, Aneja J, Reyor LL, Allen TM, Lohse AW, McGovern B, Chung RT, Kwok WW, Kim AY, Lauer GM (2012) Broadly directed virus-specific CD4+ T cell responses are primed during acute hepatitis $\mathrm{C}$ infection, but rapidly disappear from human blood with viral persistence. J Exp Med 209(1):61-75

30. Grakoui A, Shoukry NH, Woollard DJ, Han JH, Hanson HL, Ghrayeb J, Murthy KK, Rice CM, Walker CM (2003) HCV persistence and immune evasion in the absence of memory $\mathrm{T}$ cell help. Science 302(5645):659-662

31. Carlson JM, Listgarten J, Pfeifer N, Tan V, Kadie C, Walker BD, Ndung'u T, Shapiro R, Frater J, Brumme ZL, Goulder PJ, Heckerman D (2012) Widespread impact of HLA restriction on immune control and escape pathways of HIV-1. J Virol 86(9):5230-5243

32. Bronke C, Almeida CA, McKinnon E, Roberts SG, Keane NM, Chopra A, Carlson JM, Heckerman D, Mallal S, John M (2013) HIV escape mutations occur preferentially at HLA-binding sites of CD8 T-cell epitopes. Aids 27(6):899-905

33. Meyer-Olson D, Shoukry NH, Brady KW, Kim H, Olson DP, Hartman K, Shintani AK, Walker CM, Kalams SA (2004) Limited $\mathrm{T}$ cell receptor diversity of $\mathrm{HCV}$-specific $\mathrm{T}$ cell responses is associated with CTL escape. J Exp Med 200(3):307-319

34. Kimura Y, Gushima T, Rawale S, Kaumaya P, Walker CM (2005) Escape mutations alter proteasome processing of major histocompatibility complex class I-restricted epitopes in persistent hepatitis C virus infection. J Virol 79(8):4870-4876

35. Seifert U, Liermann H, Racanelli V, Halenius A, Wiese M, Wedemeyer H, Ruppert T, Rispeter K, Henklein P, Sijts A, Hengel H, Kloetzel PM, Rehermann B (2004) Hepatitis C virus mutation affects proteasomal epitope processing. J Clin Investig 114(2):250-259 
36. Goulder PJ, Phillips RE, Colbert RA, McAdam S, Ogg G, Nowak MA, Giangrande P, Luzzi G, Morgan B, Edwards A, McMichael AJ, Rowland-Jones S (1997) Late escape from an immunodominant cytotoxic T-lymphocyte response associated with progression to AIDS. Nat Med 3(2):212-217

37. Goulder PJ, Brander C, Tang Y, Tremblay C, Colbert RA, Addo MM, Rosenberg ES, Nguyen T, Allen R, Trocha A, Altfeld M, He S, Bunce M, Funkhouser R, Pelton SI, Burchett SK, McIntosh K, Korber BT, Walker BD (2001) Evolution and transmission of stable CTL escape mutations in HIV infection. Nature 412(6844):334-338

38. Crawford H, Lumm W, Leslie A, Schaefer M, Boeras D, Prado JG, Tang J, Farmer P, Ndung'u T, Lakhi S, Gilmour J, Goepfert P, Walker BD, Kaslow R, Mulenga J, Allen S, Goulder PJ, Hunter E (2009) Evolution of HLA-B*5703 HIV-1 escape mutations in HLA-B*5703-positive individuals and their transmission recipients. J Exp Med 206(4):909-921

39. International HIVCS, Pereyra F, Jia X, McLaren PJ, Telenti A, de Bakker PI, Walker BD, Ripke S, Brumme CJ, Pulit SL, Carrington M, Kadie CM, Carlson JM, Heckerman D, Graham RR, Plenge RM, Deeks SG, Gianniny L, Crawford G, Sullivan J, Gonzalez E, Davies L, Camargo A, Moore JM, Beattie N, Gupta S, Crenshaw A, Burtt NP, Guiducci C, Gupta N, Gao X, Qi Y, Yuki Y, Piechocka-Trocha A, Cutrell E, Rosenberg R, Moss KL, Lemay P, O’Leary J, Schaefer T, Verma P, Toth I, Block B, Baker B, Rothchild A, Lian J, Proudfoot J, Alvino DM, Vine S, Addo MM, Allen TM, Altfeld M, Henn MR, Le Gall S, Streeck H, Haas DW, Kuritzkes DR, Robbins GK, Shafer RW, Gulick RM, Shikuma CM, Haubrich R, Riddler S, Sax PE, Daar ES, Ribaudo HJ, Agan B, Agarwal S, Ahern RL, Allen BL, Altidor S, Altschuler EL, Ambardar S, Anastos K, Anderson B, Anderson V, Andrady U, Antoniskis D, Bangsberg D, Barbaro D, Barrie W, Bartczak J, Barton S, Basden P, Basgoz N, Bazner S, Bellos NC, Benson AM, Berger J, Bernard NF, Bernard AM, Birch C, Bodner SJ, Bolan RK, Boudreaux ET, Bradley M, Braun JF, Brndjar JE, Brown SJ, Brown K, Brown ST, Burack J, Bush LM, Cafaro V, Campbell O, Campbell J, Carlson RH, Carmichael JK, Casey KK, Cavacuiti C, Celestin G, Chambers ST, Chez N, Chirch LM, Cimoch PJ, Cohen D, Cohn LE, Conway B, Cooper DA, Cornelson B, Cox DT, Cristofano MV, Cuchural G Jr, Czartoski JL, Dahman JM, Daly JS, Davis BT, Davis K, Davod SM, DeJesus E, Dietz CA, Dunham E, Dunn ME, Ellerin TB, Eron JJ, Fangman JJ, Farel CE, Ferlazzo H, Fidler S, Fleenor-Ford A, Frankel R, Freedberg KA, French NK, Fuchs JD, Fuller JD, Gaberman J, Gallant JE, Gandhi RT, Garcia E, Garmon D, Gathe JC Jr, Gaultier CR, Gebre W, Gilman FD, Gilson I, Goepfert PA, Gottlieb MS, Goulston C, Groger RK, Gurley TD, Haber S, Hardwicke R, Hardy WD, Harrigan PR, Hawkins TN, Heath S, Hecht FM, Henry WK, Hladek M, Hoffman RP, Horton JM, Hsu RK, Huhn GD, Hunt P, Hupert MJ, Illeman ML, Jaeger H, Jellinger RM, John M, Johnson JA, Johnson KL, Johnson H, Johnson K, Joly J, Jordan WC, Kauffman CA, Khanlou H, Killian RK, Kim AY, Kim DD, Kinder CA, Kirchner JT, Kogelman L, Kojic EM, Korthuis PT, Kurisu W, Kwon DS, LaMar M, Lampiris H, Lanzafame M, Lederman MM, Lee DM, Lee JM, Lee MJ, Lee ET, Lemoine J, Levy JA, Llibre JM, Liguori MA, Little SJ, Liu AY, Lopez AJ, Loutfy MR, Loy D, Mohammed DY, Man A, Mansour MK, Marconi VC, Markowitz M, Marques R, Martin JN, Martin HL Jr, Mayer KH, McElrath MJ, McGhee TA, McGovern BH, McGowan K, McIntyre D, McLeod GX, Menezes P, Mesa G, Metroka CE, Meyer-Olson D, Miller AO, Montgomery K, Mounzer KC, Nagami EH, Nagin I, Nahass RG, Nelson MO, Nielsen C, Norene DL, O'Connor DH, Ojikutu BO, Okulicz J, Oladehin OO, Oldfield EC 3rd, Olender SA, Ostrowski M, Owen WF Jr, Pae E, Parsonnet J, Pavlatos AM, Perlmutter AM, Pierce MN, Pincus JM, Pisani L, Price LJ, Proia L, Prokesch RC, Pujet
HC, Ramgopal M, Rathod A, Rausch M, Ravishankar J, Rhame FS, Richards CS, Richman DD, Rodes B, Rodriguez M, Rose RC 3rd, Rosenberg ES, Rosenthal D, Ross PE, Rubin DS, Rumbaugh E, Saenz L, Salvaggio MR, Sanchez WC, Sanjana VM, Santiago S, Schmidt W, Schuitemaker H, Sestak PM, Shalit P, Shay W, Shirvani VN, Silebi VI, Sizemore JM Jr, Skolnik PR, Sokol-Anderson M, Sosman JM, Stabile P, Stapleton JT, Starrett S, Stein F, Stellbrink HJ, Sterman FL, Stone VE, Stone DR, Tambussi G, Taplitz RA, Tedaldi EM, Telenti A, Theisen W, Torres R, Tosiello L, Tremblay C, Tribble MA, Trinh PD, Tsao A, Ueda P, Vaccaro A, Valadas E, Vanig TJ, Vecino I, Vega VM, Veikley W, Wade BH, Walworth C, Wanidworanun C, Ward DJ, Warner DA, Weber RD, Webster D, Weis S, Wheeler DA, White DJ, Wilkins E, Winston A, Wlodaver CG, van't Wout A, Wright DP, Yang OO, Yurdin DL, Zabukovic BW, Zachary KC, Zeeman B, Zhao M (2010) The major genetic determinants of HIV-1 control affect HLA class I peptide presentation. Science 330(6010):1551-1557

40. McKiernan SM, Hagan R, Curry M, McDonald GS, Kelly A, Nolan N, Walsh A, Hegarty J, Lawlor E, Kelleher D (2004) Distinct MHC class I and II alleles are associated with hepatitis $\mathrm{C}$ viral clearance, originating from a single source. Hepatology 40(1):108-114

41. Thio CL, Gao X, Goedert JJ, Vlahov D, Nelson KE, Hilgartner MW, O'Brien SJ, Karacki P, Astemborski J, Carrington M, Thomas DL (2002) HLA-Cw*04 and hepatitis C virus persistence. J Virol 76(10):4792-4797

42. Hraber P, Kuiken C, Yusim K (2007) Evidence for human leukocyte antigen heterozygote advantage against hepatitis $\mathrm{C}$ virus infection. Hepatology 46(6):1713-1721

43. Kelleher AD, Long C, Holmes EC, Allen RL, Wilson J, Conlon C, Workman C, Shaunak S, Olson K, Goulder P, Brander C, Ogg G, Sullivan JS, Dyer W, Jones I, McMichael AJ, Rowland-Jones S, Phillips RE (2001) Clustered mutations in HIV-1 gag are consistently required for escape from HLA-B27-restricted cytotoxic T lymphocyte responses. J Exp Med 193(3):375-386

44. Miura T, Brockman MA, Schneidewind A, Lobritz M, Pereyra F, Rathod A, Block BL, Brumme ZL, Brumme CJ, Baker B, Rothchild AC, Li B, Trocha A, Cutrell E, Frahm N, Brander C, Toth I, Arts EJ, Allen TM, Walker BD (2009) HLA-B57/B*5801 human immunodeficiency virus type 1 elite controllers select for rare gag variants associated with reduced viral replication capacity and strong cytotoxic T-lymphocyte recognition. J Virol 83(6):2743-2755

45. Miura T, Brumme CJ, Brockman MA, Brumme ZL, Pereyra F, Block BL, Trocha A, John M, Mallal S, Harrigan PR, Walker BD (2009) HLA-associated viral mutations are common in human immunodeficiency virus type 1 elite controllers. J Virol 83(7):3407-3412

46. Brockman MA, Brumme ZL, Brumme CJ, Miura T, Sela J, Rosato PC, Kadie CM, Carlson JM, Markle TJ, Streeck H, Kelleher AD, Markowitz M, Jessen H, Rosenberg E, Altfeld M, Harrigan PR, Heckerman D, Walker BD, Allen TM (2010) Early selection in Gag by protective HLA alleles contributes to reduced HIV-1 replication capacity that may be largely compensated for in chronic infection. J Virol 84(22):11937-11949

47. Goepfert PA, Lumm W, Farmer P, Matthews P, Prendergast A, Carlson JM, Derdeyn CA, Tang J, Kaslow RA, Bansal A, Yusim K, Heckerman D, Mulenga J, Allen S, Goulder PJ, Hunter E (2008) Transmission of HIV-1 Gag immune escape mutations is associated with reduced viral load in linked recipients. J Exp Med 205(5):1009-1017

48. Altfeld M, Allen TM (2006) Hitting HIV where it hurts: an alternative approach to HIV vaccine design. Trends Immunol 27(11):504-510

49. Chen H, Ndhlovu ZM, Liu D, Porter LC, Fang JW, Darko S, Brockman MA, Miura T, Brumme ZL, Schneidewind A, 
Piechocka-Trocha A, Cesa KT, Sela J, Cung TD, Toth I, Pereyra F, Yu XG, Douek DC, Kaufmann DE, Allen TM, Walker BD (2012) TCR clonotypes modulate the protective effect of HLA class I molecules in HIV-1 infection. Nat Immunol 13(7):691-700

50. Neumann-Haefelin C, McKiernan S, Ward S, Viazov S, Spangenberg HC, Killinger T, Baumert TF, Nazarova N, Sheridan I, Pybus O, von Weizsacker F, Roggendorf M, Kelleher D, Klenerman P, Blum HE, Thimme R (2006) Dominant influence of an HLA-B27 restricted $\mathrm{CD} 8+\mathrm{T}$ cell response in mediating $\mathrm{HCV}$ clearance and evolution. Hepatology 43(3):563-572

51. Fitzmaurice K, Petrovic D, Ramamurthy N, Simmons R, Merani S, Gaudieri S, Sims S, Dempsey E, Freitas E, Lea S, McKiernan S, Norris S, Long A, Kelleher D, Klenerman P (2011) Molecular footprints reveal the impact of the protective HLA-A*03 allele in hepatitis C virus infection. Gut 60(11):1563-1571

52. Kim AY, Kuntzen T, Timm J, Nolan BE, Baca MA, Reyor LL, Berical AC, Feller AJ, Johnson KL, Schulze zur Wiesch J, Robbins GK, Chung RT, Walker BD, Carrington M, Allen TM, Lauer GM (2011) Spontaneous control of HCV is associated with expression of HLA-B 57 and preservation of targeted epitopes. Gastroenterology 140(2):686-696

53. Ruhl M, Chhatwal P, Strathmann H, Kuntzen T, Bankwitz D, Skibbe K, Walker A, Heinemann FM, Horn PA, Allen TM, Hoffmann D, Pietschmann T, Timm J (2012) Escape from a dominant HLA-B*15-restricted CD8+ $\mathrm{T}$ cell response against hepatitis $\mathrm{C}$ virus requires compensatory mutations outside the epitope. $\mathrm{J}$ Virol 86(2):991-1000

54. Ray SC, Fanning L, Wang XH, Netski DM, Kenny-Walsh E, Thomas DL (2005) Divergent and convergent evolution after a common-source outbreak of hepatitis C virus. J Exp Med 201(11):1753-1759

55. Honegger JR, Kim S, Price AA, Kohout JA, McKnight KL, Prasad MR, Lemon SM, Grakoui A, Walker CM (2013) Loss of immune escape mutations during persistent HCV infection in pregnancy enhances replication of vertically transmitted viruses. Nat Med 19(11):1529-1533

56. Neumann-Haefelin C, Oniangue-Ndza C, Kuntzen T, Schmidt J, Nitschke K, Sidney J, Caillet-Saguy C, Binder M, Kersting N, Kemper MW, Power KA, Ingber S, Reyor LL, Hills-Evans K, Kim AY, Lauer GM, Lohmann V, Sette A, Henn MR, Bressanelli S, Thimme R, Allen TM (2011) Human leukocyte antigen B27 selects for rare escape mutations that significantly impair hepatitis $\mathrm{C}$ virus replication and require compensatory mutations. Hepatology 54(4):1157-1166

57. Dazert E, Neumann-Haefelin C, Bressanelli S, Fitzmaurice K, Kort J, Timm J, McKiernan S, Kelleher D, Gruener N, Tavis JE, Rosen HR, Shaw J, Bowness P, Blum HE, Klenerman P, Bartenschlager R, Thimme R (2009) Loss of viral fitness and cross-recognition by $\mathrm{CD} 8+\mathrm{T}$ cells limit $\mathrm{HCV}$ escape from a protective HLA-B27-restricted human immune response. J Clin Investig 119(2):376-386

58. Oniangue-Ndza C, Kuntzen T, Kemper M, Berical A, Wang YE, Neumann-Haefelin C, Foote PK, Hills-Evans K, Reyor LL, Kane $\mathrm{K}$, Gladden AD, Bloom AK, Power KA, Thimme R, Lauer GM, Henn MR, Kim AY, Allen TM (2011) Compensatory mutations restore the replication defects caused by cytotoxic $\mathrm{T}$ lymphocyte escape mutations in hepatitis $\mathrm{C}$ virus polymerase. J Virol 85(22):11883-11890

59. Neumann-Haefelin C, Timm J, Schmidt J, Kersting N, Fitzmaurice $\mathrm{K}$, Oniangue-Ndza C, Kemper MN, Humphreys I, McKiernan S, Kelleher D, Lohmann V, Bowness P, Huzly D, Rosen HR, Kim AY, Lauer GM, Allen TM, Barnes E, Roggendorf M, Blum HE, Thimme R (2010) Protective effect of human leukocyte antigen $\mathrm{B} 27$ in hepatitis $\mathrm{C}$ virus infection requires the presence of a genotype-specific immunodominant CD8+ T-cell epitope. Hepatology 51(1):54-62
60. Ziegler S, Ruhl M, Tenckhoff H, Wiese M, Heinemann FM, Horn PA, Spengler U, Neumann-Haefelin C, Nattermann J, Timm J, East-German HCVSG (2013) Susceptibility to chronic hepatitis $\mathrm{C}$ virus infection is influenced by sequence differences in immunodominant CD8 + T cell epitopes. J Hepatol 58(1):24-30

61. Wolfl M, Rutebemberwa A, Mosbruger T, Mao Q, Li HM, Netski D, Ray SC, Pardoll D, Sidney J, Sette A, Allen T, Kuntzen T, Kavanagh DG, Kuball J, Greenberg PD, Cox AL (2008) Hepatitis $\mathrm{C}$ virus immune escape via exploitation of a hole in the $\mathrm{T}$ cell repertoire. J Immunol 181(9):6435-6446

62. Giugliano S, Oezkan F, Bedrejowski M, Kudla M, Reiser M, Viazov S, Scherbaum N, Roggendorf M, Timm J (2009) Degree of cross-genotype reactivity of hepatitis $\mathrm{C}$ virus-specific CD8+ T cells directed against NS3. Hepatology 50(3):707-716

63. Wherry EJ (2011) T cell exhaustion. Nat Immunol 12(6):492-499

64. Bengsch B, Seigel B, Ruhl M, Timm J, Kuntz M, Blum HE, Pircher H, Thimme R (2010) Coexpression of PD-1, 2B4, CD160 and KLRG1 on exhausted HCV-specific CD8+ T cells is linked to antigen recognition and $\mathrm{T}$ cell differentiation. PLoS Pathog 6(6): 1000947

65. Golden-Mason L, Palmer BE, Kassam N, Townshend-Bulson L, Livingston S, McMahon BJ, Castelblanco N, Kuchroo V, Gretch DR, Rosen HR (2009) Negative immune regulator Tim-3 is overexpressed on $\mathrm{T}$ cells in hepatitis $\mathrm{C}$ virus infection and its blockade rescues dysfunctional CD4+ and CD8+ T cells. J Virol 83(18):9122-9130

66. Urbani S, Amadei B, Tola D, Massari M, Schivazappa S, Missale G, Ferrari C (2006) PD-1 expression in acute hepatitis C virus $(\mathrm{HCV})$ infection is associated with $\mathrm{HCV}$-specific CD8 exhaustion. J Virol 80(22):11398-11403

67. Radziewicz H, Ibegbu CC, Fernandez ML, Workowski KA, Obideen K, Wehbi M, Hanson HL, Steinberg JP, Masopust D, Wherry EJ, Altman JD, Rouse BT, Freeman GJ, Ahmed R, Grakoui A (2007) Liver-infiltrating lymphocytes in chronic human hepatitis $\mathrm{C}$ virus infection display an exhausted phenotype with high levels of PD-1 and low levels of CD127 expression. J Virol 81(6):2545-2553

68. Nakamoto N, Cho H, Shaked A, Olthoff K, Valiga ME, Kaminski M, Gostick E, Price DA, Freeman GJ, Wherry EJ, Chang KM (2009) Synergistic reversal of intrahepatic HCV-specific CD8 T cell exhaustion by combined PD-1/CTLA-4 blockade. PLoS Pathog 5(2):e1000313

69. Schlaphoff V, Lunemann S, Suneetha PV, Jaroszewicz J, Grabowski J, Dietz J, Helfritz F, Bektas H, Sarrazin C, Manns MP, Cornberg M, Wedemeyer H (2011) Dual function of the NK cell receptor 2B4 (CD244) in the regulation of HCV-specific CD8+ T cells. PLoS Pathog 7(5):e1002045

70. McMahan RH, Golden-Mason L, Nishimura MI, McMahon BJ, Kemper M, Allen TM, Gretch DR, Rosen HR (2010) Tim-3 expression on PD-1+ HCV-specific human CTLs is associated with viral persistence, and its blockade restores hepatocytedirected in vitro cytotoxicity. J Clin Investig 120(12):4546-4557

71. Kasprowicz V, Kang YH, Lucas M, Schulze zur Wiesch J, Kuntzen T, Fleming V, Nolan BE, Longworth S, Berical A, Thimme R, Lewis-Ximenez L, Allen TM, Kim AY, Klenerman P, Lauer GM (2010) Hepatitis C virus (HCV) sequence variation induces an $\mathrm{HCV}$-specific T-cell phenotype analogous to spontaneous resolution. J Virol 84(3):1656-1663

72. Rutebemberwa A, Ray SC, Astemborski J, Levine J, Liu L, Dowd KA, Clute S, Wang C, Korman A, Sette A, Sidney J, Pardoll DM, Cox AL (2008) High-programmed death-1 levels on hepatitis C virus-specific $\mathrm{T}$ cells during acute infection are associated with viral persistence and require preservation of cognate antigen during chronic infection. J Immunol 181(12):8215-8225

73. Seigel B, Bengsch B, Lohmann V, Bartenschlager R, Blum HE, Thimme R (2013) Factors that determine the antiviral efficacy 
of HCV-specific CD8(+) T cells ex vivo. Gastroenterology 144(2):426-436

74. Habersetzer F, Honnet G, Bain C, Maynard-Muet M, Leroy V, Zarski JP, Feray C, Baumert TF, Bronowicki JP, Doffoel M, Trepo C, Agathon D, Toh ML, Baudin M, Bonnefoy JY, Limacher JM, Inchauspe G (2011) A poxvirus vaccine is safe, induces T-cell responses, and decreases viral load in patients with chronic hepatitis C. Gastroenterology 141(3):890-899

75. Gardiner D, Lalezari J, Lawitz E, DiMicco M, Ghalib R, Reddy KR, Chang KM, Sulkowski M, Marro SO, Anderson J, He B, Kansra V, McPhee F, Wind-Rotolo M, Grasela D, Selby M, Korman AJ, Lowy I (2013) A randomized, double-blind, placebocontrolled assessment of BMS-936558, a fully human monoclonal antibody to programmed death-1 (PD-1), in patients with chronic hepatitis $\mathrm{C}$ virus infection. PLoS One 8(5):e63818

76. Fuller MJ, Callendret B, Zhu B, Freeman GJ, Hasselschwert DL, Satterfield W, Sharpe AH, Dustin LB, Rice CM, Grakoui A, Ahmed R, Walker CM (2013) Immunotherapy of chronic hepatitis $C$ virus infection with antibodies against programmed cell death-1 (PD-1). Proc Natl Acad Sci USA 110(37):15001-15006

77. Cox AL, Thomas DL (2013) Hepatitis C virus vaccines among people who inject drugs. Clin Infect Dis off Publ Infect Dis Soci Am 57(Suppl 2):S46-S50

78. Grebely J, Dore GJ (2014) Can hepatitis C virus infection be eradicated in people who inject drugs? Antivir Res 104:62-72
79. Honegger JR, Zhou Y, Walker CM (2014) Will there be a vaccine to prevent HCV infection? Semin Liver Dis 34(1):79-88. doi:10. 1055/s-0034-1371081

80. Callendret B, Eccleston HB, Hall S, Satterfield W, Capone S, Folgori A, Cortese R, Nicosia A, Walker CM (2014) T-cell immunity and hepatitis $C$ virus reinfection after cure of chronic hepatitis $C$ with an interferon-free antiviral regimen in a chimpanzee. Hepatology 60(5):1531-1540. doi:10.1002/hep.27278

81. Kosinska AD, Zhang E, Johrden L, Liu J, Seiz PL, Zhang X, Ma Z, Kemper T, Fiedler M, Glebe D, Wildner O, Dittmer U, Lu M, Roggendorf M (2013) Combination of DNA prime-adenovirus boost immunization with entecavir elicits sustained control of chronic hepatitis B in the woodchuck model. PLoS Pathog 9(6):e1003391

82. Liu J, Zhang E, Ma Z, Wu W, Kosinska A, Zhang X, Moller I, Seiz P, Glebe D, Wang B, Yang D, Lu M, Roggendorf M (2014) Enhancing virus-specific immunity in vivo by combining therapeutic vaccination and PD-L1 blockade in chronic hepadnaviral infection. PLoS Pathog 10(1):e1003856

83. Bertoletti A, Costanzo A, Chisari FV, Levrero M, Artini M, Sette A, Penna A, Giuberti T, Fiaccadori F, Ferrari C (1994) Cytotoxic $\mathrm{T}$ lymphocyte response to a wild type hepatitis $\mathrm{B}$ virus epitope in patients chronically infected by variant viruses carrying substitutions within the epitope. J Exp Med 180(3):933-943 